УДК 581. : 576.5 : 634.224

DOI 10.30679/2219-5335-2021-1-67-162-176

ДИНАМИКА СОДЕРЖАНИЯ
ФЕНОЛЬНЫХ СОЕДИНЕНИЙ
В ВИНОГРАДНОЙ ЛОЗЕ
В СВЯЗИ С ЗИМОСТОЙКОСТЬЮ*

Ненько Наталия Ивановна

д-р с.-х. наук, профессор

главный научный сотрудник

лаборатории физиологии

и биохимии растений

e-mail: nenko.nataliya@yandex.ru

Киселева Галина Константиновна

канд. биол. наук

старший научный сотрудник

лаборатории физиологии

и биохимии растений

e-mail: galina-kiseleva-1960@mail.ru

Ильина Ирина Анатольевна

д-р техн. наук, профессор

заместитель директора по науке

e-mail:kubansad@kubannet.ru

Соколова Виктория Викторовна

канд. с.-х. наук

заведующая научнообразовательным

сектором

e-mail: KudryshovaVV@yandex.ru

Запорожец Наталья Михайловна

канд. с-х. наук

учёный секретарь

e-mail: nat_zaporozhec@mail.ru

Федеральное государственное бюджетное научное учреждение «Северо-Кавказский федеральный научный центр садоводства, виноградарства, виноделия», Краснодар, Россия
UDC 581. : 576.5 : 634.224

DOI 10.30679/2219-5335-2021-1-67-162-176

\section{DYNAMICS OF THE CONTENT \\ OF PHENOLIC SUBSTANCES \\ IN THE GRAPE VINE IN RELATION TO WINTER RESISTANCE*}

\author{
Nenko Nataliya Ivanovna \\ Dr. Sci. Agr., Professor \\ Chief Research Associate \\ of Plant Physiology \\ and Biochemistry Laboratory \\ e-mail: nenko.nataliya@yandex.ru
}

Kiseleva Galina Konstantinovna

Cand. Biol. Sci.

Senior Research Associate

of Plant Physiology

and Biochemistry Laboratory

e-mail: galina-kiseleva-1960@mail.ru

Ilina Irina Anatolyevna

Dr. Tech. Sci., Professor

Deputy Chief for Science

e-mail: kubansad@kubannet.ru

Sokolova Viktoria Viktorovna

Cand. Agr. Sci.

Head of Scientific

Educational Sector

e-mail: KudryshovaVV@yandex.ru

Zaporozhets Natalia Mikhailovna

Cand. Agr. Sci.

Scientific Secretary

e-mail: nat_zaporozhec@mail.ru

Federal State Scientific

Budget Institution

"North Caucasian Federal

Scientific Center of Horticulture,

Viticulture, Wine-making»,

Krasnodar, Russia

\footnotetext{
Исследование выполнено при финансовой поддержке Кубанского научного фонда в рамках научного проекта № МФИ-20.1/19

* The research was carried out with the financial support of the Kuban science Foundation in the framework of the scientific project № MFI-20.1/19
} 
В нестабильных условиях Анапо-

Таманской зоны Краснодарского края важном регионе возделывания винограда проблема его устойчивости к стрессам зимнего периода является актуальной. В связи с этим продолжается поиск новых диагностических критериев зимостойкости, способствующих выявлению сортов винограда, адаптированных к современным условиям меняющегося климата. Цель данной работы - провести Сравнительные исследования сортов Винограда различного экологогеографического происхождения по динамике содержания фенольных соединений в коре однолетних побегов растений в условиях зимнего периода и выделить зимостойкие сорта по этому показателю. Проведенные исследования подтвердили ранее установленный факт вовлеченности фенольных соединений в механизм защиты виноградных растений от неблагоприятных зимних условий. В наших исследованиях выявлены количественные изменения содержания антоцианов, халконов, хлорогеновой и кофейной кислот в исследуемых органах растений винограда изучаемых сортов в зимний период. Степень вклада каждого вида фенольных соединений в защитную систему была различной и определялась сортовой принадлежностью. Установлено, что у сортов Достойный, Восторг, Зариф антоцианы и халконы активно участвуют в криопротекторной функции. У данных сортов винограда отмечено максимальное суммарное содержание антоцианов (12,3-12,9 усл. ед.) и халконов (21,5-24,8 усл. ед.) в исследуемый период. Защитная функция хлорогеновой и кофейной кислот не совсем очевидна. Показано, что динамика содержания антоцианов и халконов в коре однолетних побегов виноградных растений может служить одним из косвенных методов оценки зимостойкости сортов винограда при использовании в селекционных целях.
Under the unstable conditions of the Anapo-Taman zone of Krasnodar Territory - an important region $\mathrm{f}$ or the cultivation of grapes - the problem of its resistance to the stresses of the winter period is urgent. In this regard, the search for new diagnostic indicators of winter hardiness continues, contributing to the identification of grape varieties adapted to modern conditions of a changing climate. The purpose of this work is to carry out comparative studies of grape varieties of various ecological and geographical origin according to the dynamics of the content of phenolic substances in the bark of one-year shoots under in the conditions of the winter period and to distinguish winter-hardy varieties using this indicator. The studies carried out have confirmed the previously fact established of the involvement of phenolic substances in the mechanism of grape plant protection against unfavorable winter conditions. In our studies, there were quantitative changes in the content of anthocyanins, chalcones, chlorogenic and caffeic acids in the studied grape organs of varieties under study during the winter period. The degree of contribution of each type of phenolic substance to the defense system was different and was determined by the variety. It was found that anthocyanins and chalcones are actively involved in the cryoprotective function in the Dostoyny, Vostorg and Zarif varieties. In these grape varieties, the maximum total content of anthocyanins (12.3-12.9 conventional units) and chalcones (21.5-24.8 conventional units) was noted during period under study. The protective function of chlorogenic and caffeic acids is not entirely clear. It is shown that the dynamics of anthocyanins and chalcones content in the bark of annual grape shoots studied plants can be one of the indirect methods of assessing the winter hardiness of grape varieties for breeding purposes. 
Ключевые слова: ВИНОГРАД, АНТОЦИАНЫ, ХАЛКОНЫ, ФЕНОЛЬНЫЕ СОЕДИНЕНИЯ, ЗИМОСТОЙКОСТЬ, КРИОПРОТЕКТОРНАЯ ФУНКЦИЯ
Key words: GRAPES, ANTHOCYANS, CHALCONS, PHENOLIC SUBSTANCES, WINTER RESISTANCE, CRYOPROTECTIVE FUNCTION

Введение. Одним из компонентов универсальных защитных реакций растений является биосинтез фенольных соединений. Фенольные соединения (хлорогеновая, кофейная, галловая кислоты, антоцианы, халконы) представляют собой класс вторичных метаболитов, синтезирующихся большинством растений. Их функциональная роль чрезвычайно разнообразна и связана с защитными механизмами, процессами фотосинтеза, дыхания, роста и развития растений. В первую очередь, фенольные соединения - это защитные вещества при различных стрессовых воздействиях. Присутствие их в вегетативных частях растений, как правило, связывают со стрессами различной природы. Накопление фенольных соединений под влиянием неблагоприятных и стрессовых условий среды обеспечивает устойчивость растительного организма.

Некоторые авторы связывают увеличение содержания антоцианов и халконов в побегах и коре яблони в осенне-зимний период с морозоустойчивостью $[1,2]$. Известен факт активации биосинтеза антоцианов при действии низких ночных температур у винограда [3]. Повышение содержания фенольных соединений, вызванное обработкой виноградной лозы сульфатом калия, усиливало устойчивость к низким температурам [4]. Отмечено увеличение концентрации флавонолов у маслины (Olea europaea L.) в течение морозного периода (в 1,3-3,5 раз), причем наиболее существенно у сортов с низкой морозостойкостью [5]. Позже было показано, что конститутивное содержание фенольных соединений коррелирует с зимостойкостью у розы эфиромасличной [6].

Другой главной функцией антоцианов является защита растительных тканей (в первую очередь эпидермальных) от ультрафиолетовой радиации. 
Плодоводство и виноградарство Юга России № 67(1), 2021 г.

Накопление антоцианов в этом случае уменьшает поток проникающей к хлоропластам фотосинтетически активной радиации, что способствует защите реакционных центров в пластидах при возникновении стресса [7]. Кроме того, антоцианы определяют свойства древесины, коры, кожицы плодов, ягод, в том числе и винограда, обеспечивая различную их окраску [8].

Накопление фенольных соединений часто связывают с механизмами аллелопатии и защиты растений от патогенов $[9,10]$. Есть многочисленные сведения о том, что активность синтеза фенольных веществ зависит от условий произрастания растений, в частности от температуры окружающей среды [11-14]. Помимо вышеперечисленных функций фенольные соединения являются компонентами антиоксидантной защиты. Нейтрализуя активные формы кислорода, они защищают макромолекулы от повреждения свободными радикалами и поддерживают осмотический потенциал клетки [15].

В последние годы внимание исследователей привлекают данные о генах фенольного метаболизма и их локализации, а также о молекулярных маркерах, которые могут быть использованы для идентификации сортов с повышенным содержанием фенольных соединений. Хорошо изучен процесс биосинтеза антоциановых пигментов и открыто довольно много генов, которые непосредственно контролируют и регулируют антоциановый путь биосинтеза [16-18].

Принимая во внимание многочисленные биологические функции фенольных соединений в растениях, в частности их защитную роль в устойчивости растений к низким температурам, данные исследования направлены на выяснение роли этих вторичных метаболитов в защитных механизмах виноградного растения. В связи с продолжающимся поиском диагностических показателей зимостойкости для выявления сортов винограда, адаптированных к современным условиям меняющегося климата, данная работа является актуальной. 
Цель данной работы - провести сравнительные исследования сортов винограда различного эколого-географического происхождения по динамике содержания фенольных соединений в условиях зимнего периода и выделить зимостойкие сорта по этому показателю.

Объекты и методы исследований. Исследования проводились в 2018-2020 гг. на базе ампелографической коллекции ФГБНУ АЗОСВиВ, расположенной в г. Анапа, квартал технических сортов винограда на черноземе южном карбонатном, в ЦКП «Приборно-аналитический» и лаборатории физиологии и биохимии ФГБНУ СКФНЦСВВ. Растения 1995 года посадки, подвой Кобер 5ББ. Формировка - двусторонний высокоштамбовый спиральный кордон АЗОС. Схема посадки 3,0 х 2,5 м.

Объектами исследований являлись сорта - межвидовые гибриды винограда различного эколого-географического происхождения: Кристалл (контроль) - евро-амуро-американского происхождения; Красностоп АЗОС, Достойный - евро-американского происхождения; Восторг - амуро-американского происхождения; Зариф - восточно-европейского происхождения; Алиготе - западно-европейского происхождения.

Фенольные соединения (антоцианы, халконы, хлорогеновую, кофейную кислоты) определяли используя внутреннюю часть живой коры (флоэму) отделяя при помощи скальпеля опробковевшие и отмершие слои. Исследования проводили в 3-кратной повторности, каждая повторность состояла из 10 отрезков однолетних побегов. Для анализа содержания антоцианов и халконов из средней пробы коры побегов отбирали навеску 0,2 г, измельчали, добавляли 10 мл $0,1 \mathrm{~N}$ соляной кислоты, настаивали в течение 2 часов при периодическом взбалтывании. После центрифугирования интенсивность окраски измеряли на фотоколориметре ФЭК-56 при длине волны 490 нм для антоцианов и 364 нм для халконов. Результаты измерений оптической плотности выражали в условных единицах [19]. 
Содержание хлорогеновой и кофейной кислот определяли методом капиллярного электрофореза на приборе Капель 104Р согласно методике, основанной на получении электрофореграммы с помощью прямого детектирования поглощающих компонентов пробы [20]. Экспериментальные данные обрабатывали с помощью общепринятых методов вариационной статистики [21].

Обсуждение результатов. За период 2018-2020 гг. максимальная температура воздуха в декабре увеличивалась от $+12{ }^{\circ} \mathrm{C}$ до $+18{ }^{\circ} \mathrm{C}$, а минимальная температура - от $-9{ }^{\circ} \mathrm{C}$ до $-1{ }^{\circ} \mathrm{C}$. Следует отметить, что перепад температур в декабре за анализируемый период снизился на $10^{\circ} \mathrm{C}$, в январе на $12{ }^{\circ} \mathrm{C}$ и в феврале на $3{ }^{\circ} \mathrm{C}$. Среднемесячное количество осадков в декабре-феврале составляло 18,3 мм, 29 мм, 60 мм, соответственно. Это говорит о том, что климат становится более мягким.

Микроскопирование показало своевременное и полное вызревание тканей виноградной лозы: перидермы, вторичной флоэмы, камбия, вторичной ксилемы и сердцевины, в которой отложился запасной крахмал (рис. 1).

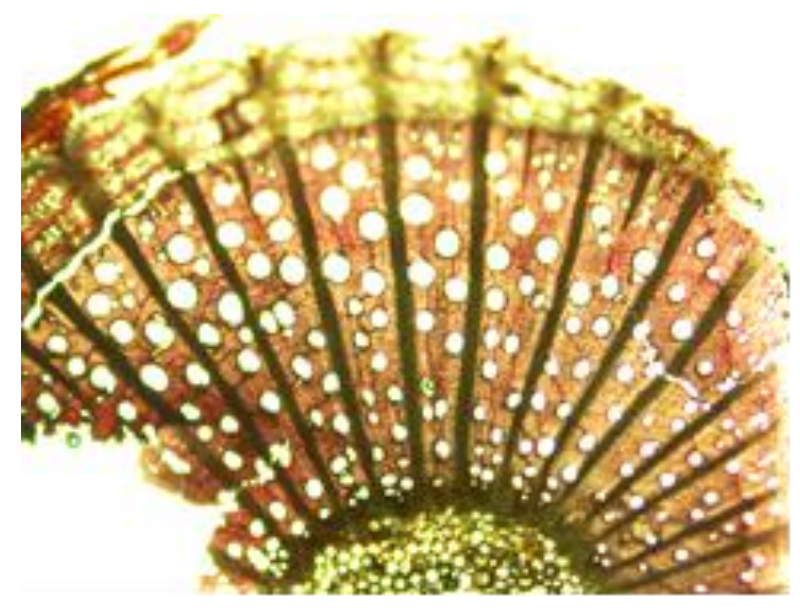

A

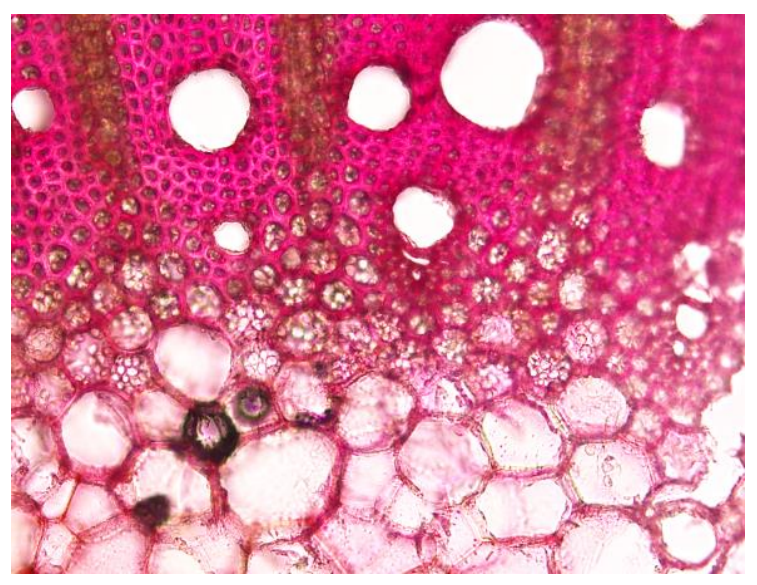

Б

Рис. 1. Микрофото годичного побега винограда сорта Восторг

в начале зимнего периода 2019-2020 гг.:

A - поперечный срез побега при увеличении 10х10;

Б - перимедуллярная зона побега с крахмальными зернами при увеличении 10х20, окраска основным фуксином 
В изучаемые зимние периоды (2018-2019 и 2019-2020 гг.) выявлены сортовые различия по содержанию антоцианов, халконов, хлорогеновой и кофейной кислот в коре однолетних побегов винограда. В 2018-2019 гг. максимальное содержание антоцианов у изучаемых сортов винограда определено в начале зимы (декабрь). Количественные показатели варьировали от 4,5 усл. ед. у сорта Алиготе до 6,5 усл. ед. у сорта Достойный (рис. 2).

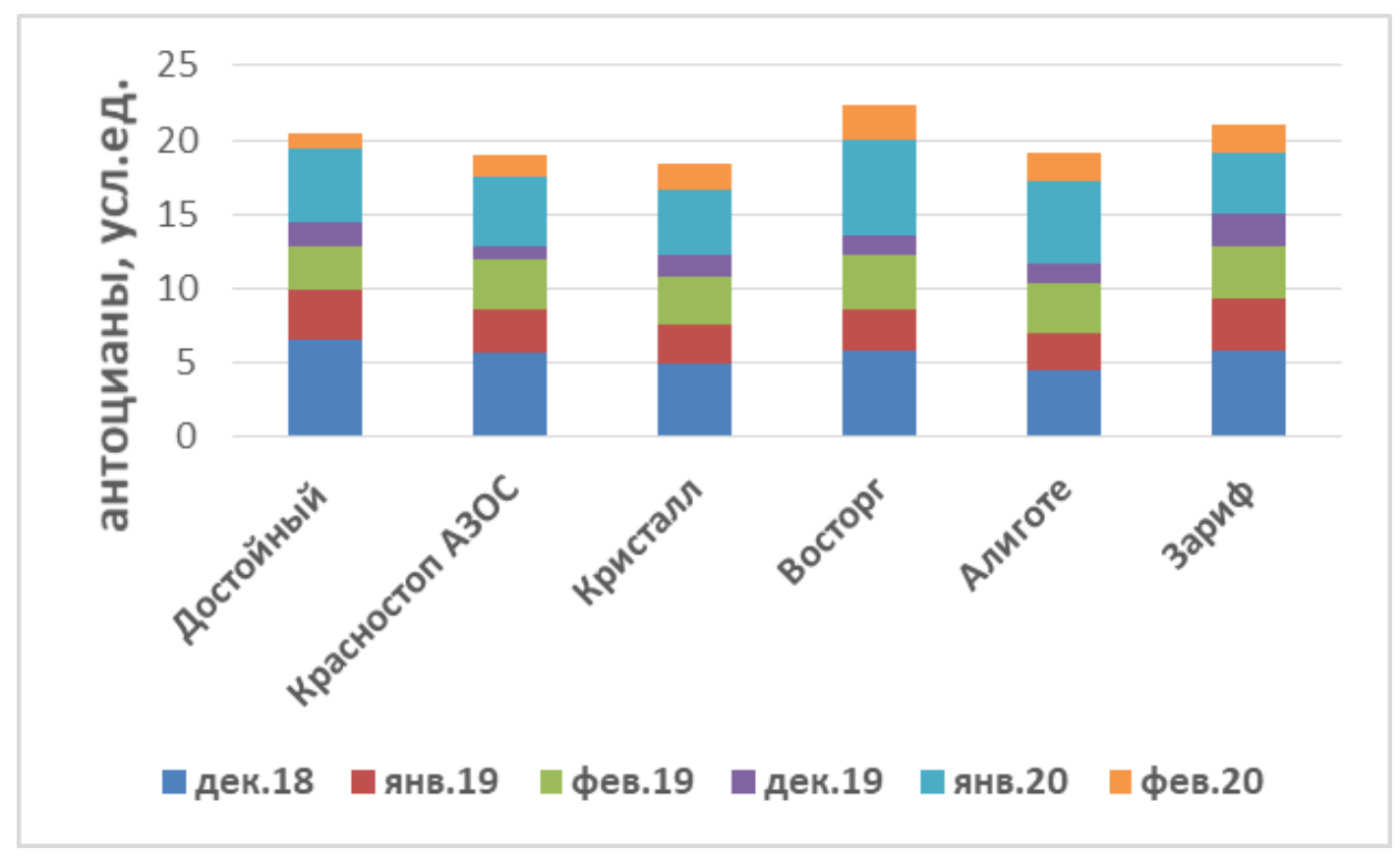

Рис. 2. Содержание антоцианов в коре однолетних побегов винограда в зимний период 2018-2020 гг. $\mathrm{HCP}_{0,5}$ : декабрь - 0,42; февраль - 0,27; март -0,45.

В январе и феврале 2019 года содержание антоцианов в коре побегов у всех сортов винограда уменьшилось в связи с их расходованием на формирование защитного ответа на условия зимнего периода. Имеются литературные данные о том, что ткани некоторых зимостойких растений содержат очень высокие концентрации антоцианов, впоследствии резко снижающиеся в течение весной [22].

В изучаемый зимний период 2019-2020 гг. наблюдалась иная динамика содержания этих соединений. Максимальное количество антоцианов у изучаемых сортов винограда наблюдалось в январе (4,0-6,4 усл. ед.), в 
декабре и феврале их содержание было меньше. По-видимому, повышенный синтез антоцианов не приурочен к началу зимнего периода, а зависит от метаболических взаимодействий с другими протекторами. Хотя по вопросу о связи между накоплением антоцианов и низкотемпературной толерантностью нет однозначного мнения, так или иначе, антоцианы могут действовать совместно с другими, более эффективными протекторами в растительной клетке, возмещая их дефицит в течение действия ряда стрессовых факторов [22].

В связи с вышесказанным изучалась динамика накопления халконов. Их содержание в изучаемый период имело аналогичную с антоцианами динамику - максимальное количество отмечено в декабре 2018 и январе 2020 года, что свидетельствует об активном участии халконов в формировании защитного ответа на неблагоприятные условия зимы (рис. 3). Повидимому, содержание халконов в коре винограда регулируется уровнем содержания антоцианов.

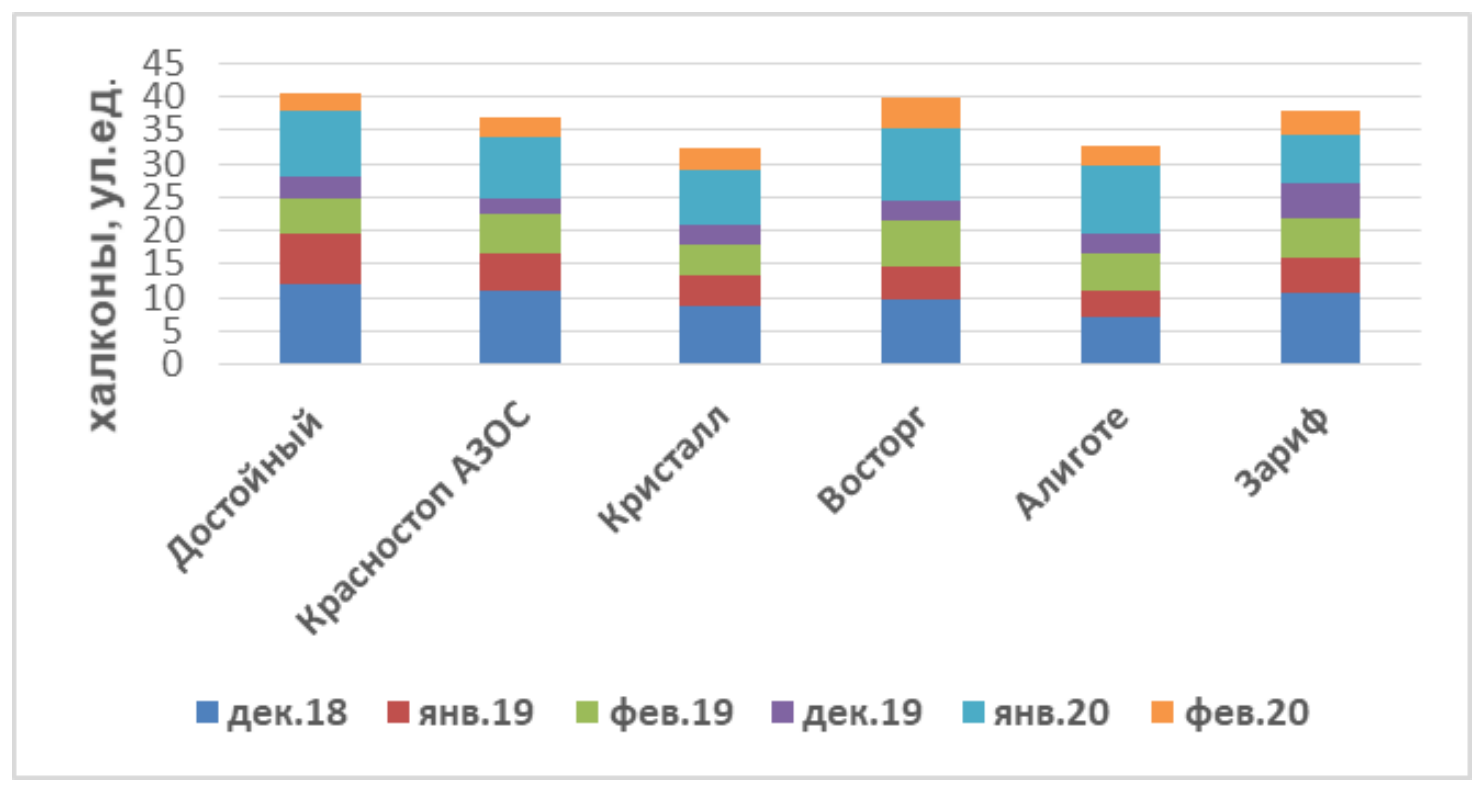

Рис. 3. Содержание халконов в коре однолетних побегов винограда в течение зимних периодов 2018-2020 гг. $\mathrm{HCP}_{0,5}$ : декабрь - 0,12; февраль - 0,29; март - 0, 81 . 
Количественные значения содержания халконов в коре однолетних побегов винограда в течение зимнего периода 2018-2020 гг. приведены в таблице 1. Установлено, что криопротекторная функция антоцианов и халконов в зимний период проявилась у сортов Достойный, Восторг, Зариф, содержащих максимальное содержание как антоцианов, так и халконов.

Таблица 1 - Содержание халконов в коре однолетних побегов винограда в зимние периоды 2018-2020 гг. (в усл. ед.)

\begin{tabular}{|l|c|c|c|c|c|c|}
\hline \multirow{2}{*}{ Сорт } & \multicolumn{3}{c|}{ Зима 2018-2019 } & \multicolumn{3}{c|}{ Зима 2019-2020 } \\
\cline { 2 - 7 } & $\begin{array}{c}\text { декабрь } \\
2018\end{array}$ & $\begin{array}{c}\text { январь } \\
2019\end{array}$ & $\begin{array}{c}\text { февраль } \\
2019\end{array}$ & $\begin{array}{c}\text { декабрь } \\
2019\end{array}$ & $\begin{array}{c}\text { январь } \\
2020\end{array}$ & $\begin{array}{c}\text { февраль } \\
2020\end{array}$ \\
\hline Достойный & 12 & 7,6 & 5,2 & 3,4 & 9,6 & 2,7 \\
\hline Красностоп АЗОС & 10,9 & 5,8 & 5,7 & 2,5 & 9,2 & 2,8 \\
\hline Кристалл & 8,7 & 4,7 & 4,6 & 2,8 & 8,1 & 3,5 \\
\hline Восторг & 9,6 & 5,1 & 6,8 & 3 & 10,7 & 4,8 \\
\hline Алиготе & 7,1 & 3,9 & 5,6 & 2,8 & 10,2 & 3,2 \\
\hline Зариф & 10,7 & 5,4 & 5,9 & 5 & 7,4 & 3,4 \\
\hline НСР 05 & 0,13 & 0,27 & 0,83 & 0,11 & 0,24 & 0,73 \\
\hline
\end{tabular}

Исследование динамики содержания хлорогеновой кислоты показало, что в зимний период 2018-2019 гг. у всех изучаемых сортов винограда в середине зимы, в январе, ее содержание повысилось, в большей степени у сортов Восторг и Зариф - 690-641 м/г сырого веса. В это время содержание антоцианов и халконов было невелико, и хлорогеновая кислота вносила определенный вклад в комплексный защитный ответ на неблагоприятные зимние условия (рис. 4).

В зимних условиях 2019-2020 гг., в декабре, когда количество антоцианов и халконов в коре растений винограда было невелико, у сортов Красностоп АЗОС и Зариф существенно повысился уровень содержания хлорогеновой кислоты - 376 и 333 мг/г сырого веса, соответственно, свидетельствующий об участии в криопротекторной функции этого метаболита. Показатели 
Плодоводство и виноградарство Юга России № 67(1), 2021 г.

содержания хлорогеновой кислоты в коре однолетних побегов изучаемых сортов винограда в зимние периоды 2018-2020 гг. приведены в таблице 2.

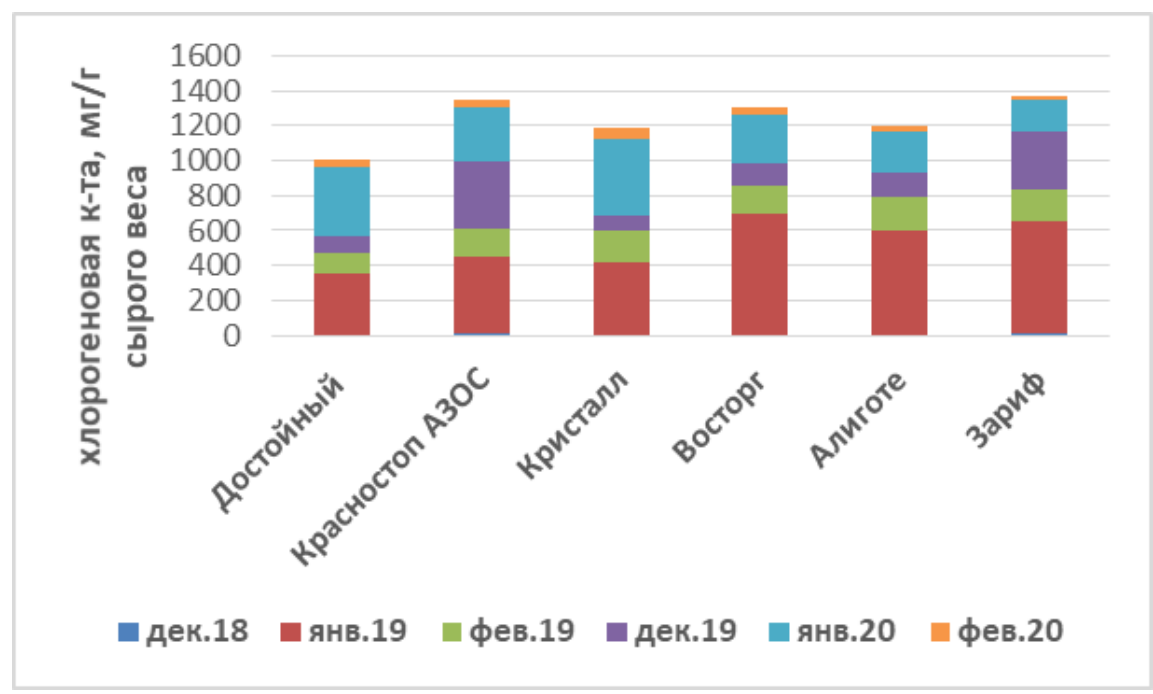

Рис. 4. Содержание хлорогеновой кислоты в коре однолетних побегов винограда в течение зимнего периода 2018-2020 гг. $\mathrm{HCP}_{0,5}$ : декабрь - 0,14; февраль - 0,39; март - 0, 82.

Таблица 2 - Содержание хлорогеновой кислоты в коре однолетних побегов винограда в зимние периоды 2018-2020 гг. (в мг /г сырого веса)

\begin{tabular}{|l|c|c|c|c|c|c|}
\hline \multirow{2}{*}{ Сорт } & \multicolumn{3}{|c|}{ Зима 2018-2019 } & \multicolumn{3}{c|}{ Зима 2019-2020 } \\
\cline { 2 - 7 } & $\begin{array}{c}\text { декабрь } \\
2018\end{array}$ & $\begin{array}{c}\text { январь } \\
2019\end{array}$ & $\begin{array}{c}\text { февраль } \\
2019\end{array}$ & $\begin{array}{c}\text { декабрь } \\
2019\end{array}$ & $\begin{array}{c}\text { январь } \\
2020\end{array}$ & $\begin{array}{c}\text { февраль } \\
2020\end{array}$ \\
\hline Достойный & 1,9 & 357 & 113,6 & 91 & 404 & 36,3 \\
\hline Красностоп АЗОС & 16,8 & 434 & 164,4 & 376 & 316 & 44,2 \\
\hline Кристалл & 4,3 & 415 & 179,4 & 88 & 440 & 58,3 \\
\hline Восторг & 0,8 & 690 & 169,2 & 121 & 286 & 42,4 \\
\hline Алиготе & 1,6 & 600 & 193,1 & 139 & 234 & 27,5 \\
\hline Зариф & 7,8 & 641 & 185,1 & 333 & 179 & 21 \\
\hline НСР 05 & 3,54 & 2,27 & 1,84 & 6,17 & 3,22 & 2,51 \\
\hline
\end{tabular}

В то же время, несмотря на то, что в январе 2020 года, как сказано выше, было отмечено высокое содержание антоцианов и халконов у изучаемых сортов винограда, наблюдался и максимальный уровень хлорогеновой кис- 
лоты. Такие данные позволяют считать, что роль хлорогеновой кислоты в защитном ответе на неблагоприятные зимние условия недостаточно ясна.

Максимальное содержание кофейной кислоты наблюдалось в январе 2019 года у сортов Достойный, Красностоп АЗОС и Зариф - 145, 135, 173 мг/Г сырого веса, а в январе 2020 года особенно много ее было определено у сорта Алиготе - 117,6 мг/г сырого веса (рис. 5).

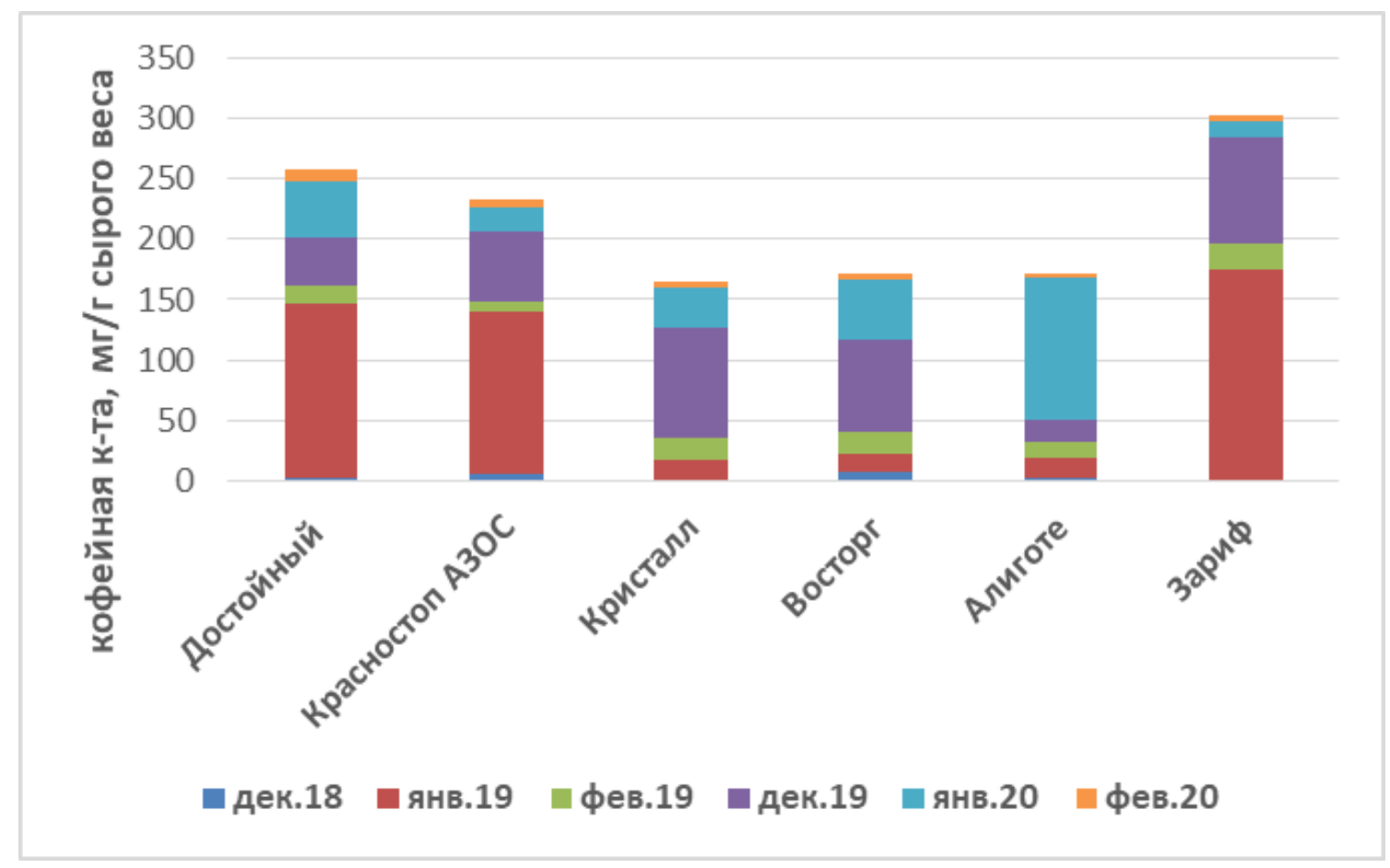

Рис. 5. Содержание кофейной кислоты в коре однолетних побегов винограда в зимние периоды 2018-2020 гг.

$\mathrm{HCP}_{0,5}$ : декабрь - 0,55; февраль - 0,24; март -0,61.

Таким образом, роль хлорогеновой и кофейной кислот у растений винограда в устойчивости к неблагоприятным зимним условиям не совсем очевидна, в отличие от других изучаемых вторичных метаболитов - антоцианов и халконов.

Bbыбды. Проведены сравнительные исследования динамики содержания фенольных соединений (антоцианов, халконов, хлорогеновой и ко- 
Плодоводство и виноградарство Юга России № 67(1), 2021 г.

фейной кислот) в коре однолетних побегов сортов винограда различного эколого-географического происхождения в зимних условиях 2018-2020 гг.

Подтвержден ранее установленный факт вовлеченности фенольных соединений в механизм защиты растений винограда от неблагоприятных зимних условий. Степень вклада каждого вида фенольных соединений в защитную систему отличался и определялся сортовой принадлежностью. Динамика содержания антоцианов и халконов показала, что у сортов Достойный, Восторг, Зариф они участвуют в криопротекторной функции. У данных сортов выявлено максимальное суммарное содержание антоцианов (12,3-12,9 усл. ед.) и халконов (21,5-24,8 усл. ед.). Это позволяет рассматривать эндогенный уровень указанных соединений в качестве индикатора состояния растений и использовать их содержание в селекционных целях в качестве диагностического показателя степени устойчивости растений к неблагоприятным зимним условиям.

Исследованная динамика накопления фенольных соединений в виноградной лозе дополняет знания об общих механизмах защитного действия этих вторичных метаболитов в зимних условиях.

\section{Литература}

1. Об устойчивости яблони к неблагоприятным условиям зимнего периода / Н.Г. Красова [и др.] // Сельскохозяйственная биология. 2014. № 1. С. 42-49.

2. Гончаровская И.В., Левон В.Ф., Клименко С.В., Кузнецов В.В. Содержание антоцианов и халконов в побегах крупноплодных сортов и кребов яблони в связи с зимостойкостью // Фенольные соединения: функциональная роль в растениях: сб. научных статей по материалам X Международного симпозиума (14-19 мая 2018 г., Москва). Москва: PRESS-BOOK.RU, 2018. C. 106-110.

3. Gaiotti F., Pastore C., Filippetti I., Lovat L., Belfiore N., Tomasi D. Low night temperature at veraison enhances the accumulation of anthocyanins in Corvina grapes (Vitis vinifera L.) // Scientific Reports. - 2018. - № 8. - P. 8719.

4. Karimi M. Potassium-induced freezing tolerance is associated with endogenous abscisic acid, polyamines and soluble sugars changes in grapevine // Scientia Horticulturae. 2017. - № 215. - P. 184-194 https://doi.org/10.1016/j.scienta.2016.12.018

5. Палий А.Е., Гребенникова О.А. [и др.] Сезонная динамика накопления фенольных соединений и изменения активности полифенолоксидазы у некоторых сортов Olea europea L. / А.Е. Палий [и др.] // Сб. науч. трудов ГБНС. Т.144. Ч.1. Ялта: ГНБС, 2017. C. 222-226. 
6. Белова И.В., Глумова Н.В., Золотилов В.А., Грунина Е.Н. О роли фенольных соединений в формировании защитного ответа новых сортов розы эфиромасличной на действие низких температур // Фенольные соединения: функциональная роль в растениях: сб. научных статей по материалам X Международного симпозиума (14-19 мая 2018 г., Москва). Москва: PRESS-BOOK.RU, 2018. C. 40-45.

7. Piccolo E.L., Landi M., Massai R., Remorini D., Guidi L. Girled-induced anthocyanin accumulation in red-leafed Prunus cerasifera: Effect on photosynthesis, photoprotection and sugar metabolism // Plant Science. - 2020. - № 294. - P. 110456 https://doi.org/10.1016/j.plantsci.2020.110456

8. Heimler D., Romani A., Ieri F. Plant polyphenol content, soil fertilization and agricultural management: (a review) // Eur. Food Res. Technol. - 2017. - № 243. - P. 1107-1115 // DOI 10.1007/s00217-016-2826-6-

9. Petkovsek M.M., Slatnar A., Stampar F., Vebric R. The influence of organic/integrated production on the content of phenolic compounds in apple leaves and fruits in four different varieties over a 2-year period // J. Sci. Food Agric. - 2010. - № 90. P. 2366-2378

10. Skłodowska M., Mikiciński A., Wielanek M., Kuźniak E., Sobiczewski P. Phenolic profiles in apple leaves and the efficacy of selected phenols against fire blight (Erwinia amylovora) // Eur. J. Plant Pathol. - 2018. - № 151. - P. 213-228 https://doi.org/10.1007/s10658-017-1368-5-

11. Degu A., Ayenew B., Cramer G.R., Fait A. Polyphenolic responses of grapevine berries to light, temperature, oxidative stress, abscisic acid and jasmonic acid show specific developmental-dependent degrees of metabolic resilience to perturbation // Food Chemistry. 2016. - № 212. - P. 828-836.

12. Gouot J.C., Smith J.P., Holzapfel B.P., Walker A.R., Barril C. Grape berry flavonoids: a review of their biochemical responses to high and extreme high temperatures // Journal of Experimental Botany. - 2019. - № 70 (2). - P. 397-423. doi:10.1093/jxb/ery392

13. Arrizabalaga M., Morales F., Oyarzun M., Delrot S., Gomès E., Irigoyen J.J., Hilbert G., Pascual I. Tempranillo clones differ in the response of berry sugar and anthocyanin accumulation to elevated temperature // Plant Science.- 2018. - № 267. - P. 74-83.

14. Azuma A. Genetic and environmental impacts on the biosynthesis of anthocyanins in grapes // The Horticulture Journal.- 2018. - № 87. - P. 1-17 doi: 10.2503/hortj.OKD-IR02 ягоды.

15. Baskar V., Venkatesh R., Ramalingam S. Flavonoids (antioxidants systems) in higher plants and their response to stresses // In: Gupta D.K., Palma J.M., Corpas F.J., eds. Antioxidants and antioxidant enzymes in higher plants. - 2018. - Cham: Springer, P. 253-268.

16. Bontpart T., Marlin T., Vialet S., Guiraud J.L., Pinasseau L., Meudec E., Sommerer N., Cheynier V., Terrier N. Two shikimate dehydrogenases, VvSDH3 and VvSDH4, are involved in gallic acid biosynthesis in grapevine // Journal of Experimental Botany. - 2016. № 67. - P. 3537-3550.

17 Azuma A., Yakushiji H., Koshita Y., Kobayashi S. Flavonoid biosynthesis-related genes in grape skin are differentially regulated by temperature and light conditions // Planta. 2012. - № 236. - P. 1067-1080.

18. Ilk N., Ding J., Ihnatowicz A., Koornneef M., Reymond M. Natural variation for anthocyanin accumulation under high-light and low-temperature stress is attributable to the enhancer of AG-4 2 (HUA2) locus in combination with production of anthocyanin pigment1 (PAP1) and PAP2 // New Phytologist. - 2015. - № 206. - P. 422-435. doi: 10.1111/nph. 13177 
19. Соловьева М.А. Оценка зимостойкости плодовых культур / Диагностика устойчивости растений к стрессовым воздействиям (методическое руководство). Ленинград: ВИР, 1988. С.163-164.

20. Методика определения массовой концентрации аскорбиновой, хлорогеновой и кофейной кислот в побегах и листьях плодовых культур и винограда с применением капиллярного электрофореза / Ю.Ф. Якуба [и др.] // Современные инструментальноаналитические методы исследования плодовых культур и винограда; под общей редакцией Н.И. Ненько. Краснодар: СКЗНИИСиВ, 2015. С. 68-73.

21. Доспехов Б.А. Методика полевого опыта (с основами статистической обработки результатов исследований). М., 1979. 463 с.

22. Чупахина Г.Н., Масленников П.В., Скрыпник Л.Н. Природные антиоксиданты (экологический аспект): монография. Калининград: Изд-во БФУ им. И. Канта, 2011. $111 \mathrm{c}$.

\section{References}

1. Ob ustojchivosti yabloni $\mathrm{k}$ neblagopriyatnym usloviyam zimnego perioda / N.G. Krasova [i dr.] // Sel'skohozyajstvennaya biologiya. 2014. № 1. S. 42-49.

2. Goncharovskaya I.V., Levon V.F., Klimenko S.V., Kuznecov V.V. Soderzhanie antocianov i halkonov $\mathrm{v}$ pobegah krupnoplodnyh sortov i krebov yabloni v svyazi s zimostojkost'yu // Fenol'nye soedineniya: funkcional'naya rol' v rasteniyah: sb. nauchnyh statej po materialam H Mezhdunarodnogo simpoziuma (14-19 maya 2018 g., Moskva). Moskva: PRESS-BOOK.RU, 2018. S. 106-110.

3. Gaiotti F., Pastore C., Filippetti I., Lovat L., Belfiore N., Tomasi D. Low night temperature at veraison enhances the accumulation of anthocya-nins in Corvina grapes (Vitis vinifera L.) // Scientific Reports. - 2018. - № 8. - P. 8719.

4. Karimi M. Potassium-induced freezing tolerance is associated with endogenous abscisic acid, polyamines and soluble sugars changes in grape-vine // Scientia Horticulturae. 2017. - № 215. - P. 184-194 https://doi.org/10.1016/j.scienta.2016.12.018

5. Palij A.E., Grebennikova O.A. [i dr.] Sezonnaya dinamika nakopleniya fenol'nyh soedinenij i izmeneniya aktivnosti polifeno-loksidazy u nekotoryh sortov Olea europea L. I A.E. Palij [i dr.] // Sb. nauch. trudov GBNS. T.144. Ch.1. Yalta: GNBS, 2017. S. 222-226.

6. Belova I.V., Glumova N.V., Zolotilov V.A., Grunina E.N. O ro-li fenol'nyh soedinenij $\mathrm{v}$ formirovanii zashchitnogo otveta novyh sortov rozy efiromaslichnoj na dejstvie nizkih temperatur // Fenol'nye soedineniya: funkcional'naya rol' v rasteniyah: sb. nauchnyh statej po materialam X Mezhdunarodnogo simpoziuma (14-19 maya 2018 g., Moskva). Moskva: PRESS-BOOK.RU, 2018. S. 40-45.

7. Piccolo E.L., Landi M., Massai R., Remorini D., Guidi L. Girledinduced anthocyanin accumulation in red-leafed Prunus cerasifera: Effect on photosynthesis, photoprotection and sugar metabolism // Plant Science. - 2020. - № 294. - P. 110456 https://doi.org/10.1016/j.plantsci.2020.110456

8. Heimler D., Romani A., Ieri F. Plant polyphenol content, soil fertilization and agricultural management: (a review) // Eur. Food Res. Technol. - 2017. - № 243. - P. 1107-1115 // DOI 10.1007/s00217-016-2826-6-

9. Petkovsek M.M., Slatnar A., Stampar F., Vebric R. The influence of organic/integrated production on the content of phenolic compounds in apple leaves and fruits in four different varieties over a 2-year period // J. Sci. Food Agric. - 2010. - № 90. P. 2366-2378 
10. Skłodowska M., Mikiciński A., Wielanek M., Kuźniak E., Sobiczewski P. Phenolic profiles in apple leaves and the efficacy of selected phenols against fire blight (Erwinia amylovora) // Eur. J. Plant Pathol. - 2018. - № 151. - P. 213-228 https://doi.org/10.1007/s10658-017-1368-5-

11. Degu A., Ayenew B., Cramer G.R., Fait A. Polyphenolic responses of grapevine berries to light, temperature, oxidative stress, abscisic acid and jasmonic acid show specific developmental-dependent degrees of metabolic resilience to perturbation // Food Chemistry. 2016. - № 212. - P. 828-836.

12. Gouot J.C., Smith J.P., Holzapfel B.P., Walker A.R., Barril C. Grape berry flavonoids: a review of their biochemical responses to high and extreme high temperatures // Journal of Experimental Botany. - 2019. - № 70 (2). - P. 397-423. doi:10.1093/jxb/ery392

13. Arrizabalaga M., Morales F., Oyarzun M., Delrot S., Gomès E., Irigoyen J.J., Hilbert G., Pascual I. Tempranillo clones differ in the response of berry sugar and anthocyanin accumulation to elevated temperature // Plant Science.- 2018. - № 267. - P. 74-83.

14. Azuma A. Genetic and environmental impacts on the biosynthesis of anthocyanins in grapes // The Horticulture Journal.- 2018. - № 87. - P. 1-17 doi: 10.2503/hortj.OKD-IR02 yagody.

15. Baskar V., Venkatesh R., Ramalingam S. Flavonoids (antioxidants systems) in higher plants and their response to stresses // In: Gupta D.K., Palma J.M., Corpas F.J., eds. Antioxidants and antioxidant enzymes in higher plants. - 2018. - Cham: Springer, P. 253-268.

16. Bontpart T., Marlin T., Vialet S., Guiraud J.L., Pinasseau L., Meudec E., Sommerer N., Cheynier V., Terrier N. Two shikimate dehydrogenases, VvSDH3 and VvSDH4, are involved in gallic acid biosynthesis in grapevine // Journal of Experimental Botany. - 2016. № 67. - P. 3537-3550.

17 Azuma A., Yakushiji H., Koshita Y., Kobayashi S. Flavonoid biosynthesis-related genes in grape skin are differentially regulated by temperature and light conditions // Planta. 2012. - № 236. - P. 1067-1080.

18. Ilk N., Ding J., Ihnatowicz A., Koornneef M., Reymond M. Natural variation for anthocyanin accumulation under high-light and low-temperature stress is attributable to the enhancer of AG-4 2 (HUA2) locus in combination with production of anthocyanin pigment1 (PAP1) and PAP2 // New Phytologist. - 2015. - № 206. - P. 422-435. doi: 10.1111/nph. 13177

19. Solov'eva M.A. Ocenka zimostojkosti plodovyh kul'tur / Diagnostika ustojchivosti rastenij k stressovym vozdejstviyam (metodicheskoe rukovodstvo). Leningrad: VIR, 1988. S. 63-164.

20. Metodika opredeleniya massovoj koncentracii askorbinovoj, hlorogenovoj i kofejnoj kislot v pobegah i list'yah plodovyh kul'tur i vinograda s primeneniem kapillyarnogo elektroforeza / Yu.F. Yakuba [i dr.] // Sovremennye instrumental'no-analiticheskie metody issledovaniya plodovyh kul'tur i vinograda; pod obshchej redakciej N.I. Nen'ko. Krasnodar: SKZNIISiV, 2015. S. 68-73.

21. Dospekhov B.A. Metodika polevogo opyta (s osnovami statisticheskoj obrabotki rezul'tatov issledovanij). M., 1979. $463 \mathrm{~s}$.

22. Chupahina G.N., Maslennikov P.V., Skrypnik L.N. Prirodnye antioksidanty (ekologicheskij aspekt): monografiya. Kaliningrad: Izd-vo BFU im. I. Kanta, 2011. $111 \mathrm{s.}$ 